\title{
Horizontal Transmission of the Mouse Mammary Tumor Virus in Cage Mates of the Same and Opposite Sex of Low and High Mammary Cancer Strain Mice
}

\author{
Junji MORIMOTO, Shunsuke IMAI, Yoshihiko TSUBURA and Jo HILGERS*
}

\author{
Dept. of Pathology, Nara Medical College, Kashihara shi, Nara, 634 \\ Japan, and * Division of Tumor Biology, The Netherlands \\ Cancer Institute, Amsterdam, The Netherlands
}

(Received 8 May 1984 / Accepted 24 October 1984)

\begin{abstract}
Horizontal transmission of mouse mammary tumor virus (MTV) was investigated in cage mates of the same and opposite sex of low (BALB/c) and high mammary cancer strains (DD/Tbr, SHN and GR). By MTVp27 and MTVgp52 radioimmunoassay, MTV antigen expression was found in the salivary glands, mammary glands and secondary male genital organs of the MTV-free $\mathrm{BALB} / \mathrm{c}$ strain. Infectivity and oncogenicity were also found in DDf or BALB/c mice by inoculating extracts of salivary gland and/or seminal vesicle in high mammary cancer strains. It is suggested that the primary source of the infectious agent in cases of caged animals of the same sex is saliva, while the primary source in cases of caged animals of the opposite sex is the seminal fluid, although additional infection through saliva cannot be ruled out in the latter case.
\end{abstract}

The discovery of an extrachromosomal factor in murine mammary cancer $[16,17]$ and the localization of that factor in the milk [5] has been reported extensively in various reviews $[6,9,20]$. Extrachromosomal male transmission has also been demonstrated repeatedly $[1,10]$ and has been reviewed in particular detail by Hilgers and Bentvelzen [11]. "Horizontal" transmission between cage mates, as opposed to vertical transmission from parent to offspring, has never been shown convincingly, although occasional reports and communications on it have appeared $[7,18,21]$ (Stutman, personal communication; Van Nie, personal communication ; see also review by Hilgers and Bentvelzen [11]).

Questions remained, however, as to how efficiently horizontal transmission between cage mates would occur and what the exact routes of transmission would be. If the mammary gland became infected, would the infection result in tumorigenesis? After more than 50 years of research on the transmission of the mammary tumor virus having resulted in the idea that this virus is only transmitted vertically, we report here that the virus can be transmitted horizontally with ease, within cages, provided the right combination of strains is used.

\section{Materials and Methods}

Mice: The DD/Tbr strain, inbred by $\mathrm{Y}$. Tsubura since 1957, has reached the 72 nd inbred generation and has an incidence of $71 \%$ mammary cancer at an average age of 10 months due to a milk-transmitted virus [13]. 
The SHN strain of Swiss origin, inbred by $H$. Nagasawa and maintained for 6 years in Nara, has a mammary tumor incidence of $89 \%$ at 7.2 months of age due to an endogenous mammary tumor viral locus, called Mtv-4[14].

The GRS/A strain (GR) derived from the Netherlands Cancer Institute via Kansai Medical University has been maintained in Nara for four years. It is a strain with an extremely high mammary cancer incidence at early age due to an endogenous viral locus, called Mtv-2[25].

The BALB/c strain, obtained from the Taisho Pharmaceuticals Co., Ltd. in 1974, has a mammary tumor incidence of $3 \%$ in the later part of the life span.

The DD/Tbrf (DDf) strain was obtained by foster-nursing $\mathrm{DD} / \mathrm{Tbr}$ mice on a C57BL strain to eliminate exogenous MTV in the milk in 1978, and no mammary tumor has ever occurred.

All strains were maintained by strict brother-sister mating.

They were fed oriental NMF pellets and received water ad libitum. Mice were kept in an animal room with a constant temperature of $22 \pm 1^{\circ} \mathrm{C}$ and $40 \%$ humidity.

A large series of genetic markers has recently been determined in mice of these various strains, showing that none of them was a "contaminated" strain (Imai et al., manuscript in preparation).

Experimental design : Four-week-old BALB/c were kept together with members of the same and opposite sex of the high mammary cancer strains (DD/Tbr, SHN and $\mathrm{GR}$ ) and $\mathrm{BALB} / \mathrm{c}$ strain as control, each 12 months of age, for 8 months until necropsy.

Preparation of extracts from organs of mice: After necropsy, the organs were homogenized in $10 \mathrm{vol}$. of $\mathrm{Ca}^{2+}$-and $\mathrm{Mg}^{2+}$ free Earle's balanced salt solution (EBSS, from Grand Island Biological Co., NY, U. S. A.). After the addition of ether, the homogenate was stirred vigorously for 3 min on a Vortex. After centrifugation at $850 \times \mathrm{g}$ for $10 \mathrm{~min}$, the ether phase was discarded and the water phase was stored overnight at $4^{\circ} \mathrm{C}$. The extract was centrifuged again and the supernatant was used for radioimmunoassay [15].

Radioimmunoassay : The purified MTVp27 and MTVgp52 proteins were kindly provided by Dr. R. Nusse of the Netherlands Cancer Institute. Iodination of MTV proteins was performed by a slight modification of the method by Strand et al. [23].

The reaction mixture was applied to a Sephadex G-25 fine column and labelled protein was obtained. Serial dilutions of test samples ( $1: 3$ steps) were made in 2 $\mathrm{mg} / \mathrm{ml} \mathrm{BSA}$ in TEN buffer containing 0.2 $\%$ Triton $\mathrm{X}-100$. Ten $\mu 1$ rabbit anti-MTV serum was added and incubated at $37^{\circ} \mathrm{C}$ for $30 \mathrm{~min}$ followed by $40 \mu 1$ labelled MTV proteins. After $4 \mathrm{hr}$ incubation at $37^{\circ} \mathrm{C}$, $30 \mu 1$ goat anti-rabbit IgG (diluted $1: 5$ ) was added. Immunocomplexes were allowed to from overnight at $4{ }^{\circ} \mathrm{C}$ and the pellets were washed twice in cold TEN buffer and spun down at $850 \mathrm{~g}$ for $20 \mathrm{~min}$ and counted.

Immunodiffusion (ID) : ID test for MTV antigen in the milk was performed with $2 \%$ Noble agar (Difco Laboratories, (Detroit Michigan U. S. A.) slides.

Ten $\mu$ l undiluted milk samples were placed in peripheral wells, and the central well was filled with $10 \mu 1$ of undiluted antiserum against MTV.

The infectivity and oncogenicity of MTV in the salivary gland and/or seminal vesicle of high mammary cancer strains (DD/Tbr, SHN) was tested in MTV-free DDf and BALB/c mice by inoculating the extracts of these organs at $0.1-0.2 \mathrm{ml}, 3-5$ times i. p. in order to examine the frequency of MTV anigen expression in the milk and mammary tumors.

\section{Results}

Female BALB/c mice together with females of three high mammary cancer strains (DD/Tbr, SHN and GR) occasionally 
became positive for MTV antigens in the salivary glands, but not in the mammary glands. The levels of antigen (MTVgp52 and MTVp27) were low. Male BALB/c mice kept together in the same cage with males of three high mammary cancer strains (DD/Tbr, SHN and GR) became MTV antigen positive at a high frequency in the salivary glands and at a lower frequency in the seminal vesicles and the prostate. Again, the level of antigen remained low and never exceeded the $40 \mathrm{ng} / \mathrm{mg}$ tissue protein. Control BALB/c mice, both sexes, did not show detectable antigens. Table 1 shows these results.

Female BALB/c mice, kept together in

Table 1. MTV antigen determination in BALB/c mice caged with high mammary cancer strain mice of the same sex

\begin{tabular}{|c|c|c|c|c|c|c|}
\hline \multirow{3}{*}{ Female cage mate } & \multicolumn{6}{|c|}{ BALB/c females } \\
\hline & \multicolumn{2}{|c|}{ Salivary glands } & \multicolumn{2}{|c|}{ Mammary glands } & & \\
\hline & MTVp27 & MTVgp52 & MTVp27 & MTVgp52 & & \\
\hline $\mathrm{DD} / \mathrm{Tbr}$ & $0 / 4^{*}$ & $1 / 4(7)^{+}$ & $0 / 4$ & $0 / 4$ & & \\
\hline SHN & $0 / 5$ & $1 / 5(3)$ & $0 / 5$ & $0 / 5$ & & \\
\hline GR & $1 / 4(14)$ & $1 / 4(11)$ & $0 / 5$ & $0 / 4$ & & \\
\hline BALB/c (Control) & $0 / 5$ & $0 / 5$ & $0 / 5$ & $0 / 5$ & & \\
\hline \multirow{3}{*}{ Male cage mate } & \multicolumn{6}{|c|}{$\mathrm{BALB} / \mathrm{c}$ males } \\
\hline & \multicolumn{2}{|c|}{ Salivary glands } & \multicolumn{2}{|c|}{ Seminal vesicle } & \multicolumn{2}{|c|}{ Prostate } \\
\hline & MTVp27 & $\overline{\text { MTVgp52 }}$ & MTVp27 & MTVgp52 & MTVp27 & MTVgp52 \\
\hline $\mathrm{DD} / \mathrm{Tbr}$ & $2 / 2(3)$ & $2 / 2(4)$ & $1 / 2(5)$ & $1 / 2(2)$ & $0 / 2$ & $0 / 2$ \\
\hline SHN & $6 / 6(18)$ & $2 / 6(39)$ & $2 / 6(9)$ & $2 / 6(28)$ & $0 / 6$ & $2 / 6(28)$ \\
\hline GR & $6 / 6(13)$ & $1 / 6(13)$ & $1 / 6(13)$ & $1 / 6(13)$ & $0 / 6$ & $2 / 6(16)$ \\
\hline BALB/c (Control) & $0 / 6$ & $0 / 6$ & $0 / 6$ & $0 / 6$ & $0 / 6$ & $0 / 6$ \\
\hline
\end{tabular}

* Number of positive animals/number of tested animals

+ In parentheses, the average amount of viral protein in nanogram per miligram tissue protein as determined by radioimmunoassay

Table 2. MTV antigen determination in BALB/c females caged with mammary cancer strain mice of the opposite sex

\begin{tabular}{|c|c|c|c|c|c|c|c|c|}
\hline \multirow{3}{*}{$\begin{array}{c}\text { High cancer strain } \\
\text { Males }\end{array}$} & \multicolumn{8}{|c|}{ BALB/c Females } \\
\hline & \multicolumn{2}{|c|}{ Salivary glands } & \multicolumn{2}{|c|}{ Mammary glands } & \multicolumn{2}{|c|}{$\mathrm{Milk}_{+}^{+}$} & \multicolumn{2}{|c|}{ Mammary tumors } \\
\hline & MTVp27 & MTVgp52 & MTVp27 & MTVgp52 & $\mathrm{I} \cdot \mathrm{II}$ & III IV & MTVp27 & MTVgp52 \\
\hline $\mathrm{DD} / \mathrm{Tbr}$ & $0 / 7^{*}$ & $1 / 7(26) !$ & $1 / 7(99)$ & $3 / 7(68)$ & $0 / 8 \quad 0 / 2$ & $0 / 30 / 1$ & $1 / 1(3660)$ & $1 / 1(1940)$ \\
\hline SHN & $4 / 11(5)$ & $8 / 11(7)$ & $5 / 11(23)$ & $8 / 11(197)$ & $1 / 62 / 5$ & $1 / 42 / 2$ & NT & NT \\
\hline GR & $3 / 7(19)$ & $4 / 7(7)$ & $3 / 7(122)$ & $3 / 7(106)$ & $0 / 4 \quad 0 / 4$ & $1 / 2 \mathrm{NT}$ & $1 / 1(680)$ & $1 / 1(2540)$ \\
\hline $\mathrm{BABL} / \mathrm{c}$ (Control) & $0 / 8$ & $0 / 8$ & $0 / 8$ & $0 / 8$ & $\begin{array}{lll}0 / 8 & 0 / 7\end{array}$ & $0 / 8 \quad 0 / 6$ & - & - \\
\hline
\end{tabular}

* Number of positive animals/number of animals tested

! In parentheses, the average amount of viral protein in nanogram per miligram tissue protein as determined by radioimmunoassay

+ Determinations in the milk for viral antigen were done by immunodiffusion test

- Lactation number

NT : not tested 
Table 3. Induction of mammary tumors in BALB/c and DDf females by inoculating extracts of male accessory sex organs and seminal fluid or salivary glands

\begin{tabular}{|c|c|c|c|c|c|c|c|}
\hline \multirow[b]{2}{*}{ Strain } & \multirow[t]{2}{*}{ Inoculum } & \multirow{2}{*}{$\begin{array}{l}\text { Recipient } \\
\text { strain }\end{array}$} & \multicolumn{3}{|c|}{ MTV antigen in milk } & \multicolumn{2}{|c|}{ Mammary tumor } \\
\hline & & & $\mathrm{I} * *$ & II & III $-\mathrm{V}$ & Incidence & Ave. Age (mo.) \\
\hline \multirow[t]{2}{*}{$\mathrm{DD} / \mathrm{Tbr}$} & Seminal fluid* & DDf & $1 / 3$ & $1 / 4$ & $4 / 4$ & $50 \%(2 / 4)$ & $13.2 \pm 1.2$ \\
\hline & Controls & & $0 / 10$ & $0 / 7$ & $1 / 17$ & $0 \quad(0 / 40)$ & - \\
\hline \multirow[t]{3}{*}{ SHN } & $\begin{array}{l}\text { Seminal vesicles* } \\
\text { and prostate }\end{array}$ & $\mathrm{BALB} / \mathrm{c}$ & $7 / 7$ & $4 / 5$ & $7 / 7$ & $68 \%(6 / 7)$ & $9.8 \pm 1.0$ \\
\hline & Salivary gland* & & $3 / 6$ & $4 / 6$ & $6 / 6$ & $67 \%(4 / 6)$ & $8.2 \pm 0.6$ \\
\hline & Controls & & $0 / 17$ & $0 / 7$ & $0 / 18$ & $3 \%(3 / 104)$ & $17.5 \pm 1.7$ \\
\hline
\end{tabular}

* $0.1-0.2 \mathrm{ml}$ of $10 \%$ suspension was injected $3-5$ times i. p.

** Lactation number

in cages with males of three high mammary cancer strains for 8 months, became MTV antigen positive in extracts from salivary glands, mammary glands and milk by radioimmunoassay and immunodiffusion test. In this case, the frequency of antigen detection was somewhat higher in the mammary glands than in the salivary glands. Milk of BALB/c females became positive when the $\mathrm{SHN}$ and GR strains were caged with them. BALB/c females may develop mammary tumors after caging with high cancer strain males. In any case, no MTV antigen was detected in any organs of control $\mathrm{BALB} / \mathrm{c}$ mice caged and mated (Table 1 and 2 ).

Mammary tumors can be induced in DDf breeding females after injection with extracts of seminal fluid (from DD/Tbr mice) and in BALB/c mice with extracts of seminal vesicles, prostate (from SHN mice) and salivary glands (from SHN mice). The incidence of infection in $\mathrm{BALB} / \mathrm{c}$ is high and the tumors occur before one year of age, in contrast to the very few late tumors in the untreated $\mathrm{BALB} / \mathrm{c}$ group. Untreated control DDf mice developed no tumors (see Table 3 ).

\section{Discussion}

It has been suspected for some time that horizontal transmission of MTV could occur because of the relatively high expression of the virus in salivary glands $[21,22]$. It is our conclusion that the higher frequency of infections between cage mate males is due to the transmission of MTV through biting, because it is well known that males are much more agressive than females, showing heavy fighting and biting. Nevertheless even in cases of caged females, between high and low (and susceptible) strain mice, MTV was transmitted occasionaly. Infection mainly takes place through the infectious saliva. This seems strange if the biting occurs at random on the body or extremities, because it is generally assumed that MTV would infect organs such as the mammary gland via certain white blood cell populations [for review, see 4], and why should the caging result in the infection of the salivary gland via the blood but not the mammary gland? Perhaps the infection occurs preferentially in the salivary gland in a more direct way when wounds are licked and saliva of the other animals, harboring the $\mathrm{B}$ particles, enters the oral cavity. If this is the case, one would also expect that $B$ particles in the milk would infect the salivary glands of the newborns more easily and earlier than the mammary gland.

The experiments described here on caging animals of the opposite sex have 
been done more frequently in the past and have also yielded infection in the females and their offspring. It has always been argued that in this case the seminal fluid, containing $\mathrm{B}$ particles in abundance, is the primary source of the infectious agent $[19,24]$. In general, the young are not infected in utero, but via the mother, whose mammary gland is thought to be infected via the blood stream [2, for the frequency of direct utero infection, see also review 11]. The present experiments, however, have shown that infected saliva also transmitted MTV via biting. Therefore, in caged mice of the opposite sex, the infectious agent was transmitted through seminal fluid as well as the saliva.

The main conclusion of our results, however, must be that the mouse mammary tumor virus can spread horizontally through a population and that the salivary glands are the most likely source of infection through agressive biting behavior, followed by licking the wounds and swallowing saliva cantaining $B$ particles though the infection via urine cannot be ruled out, because MTV antigen expression has been observed in the urinary bladder in some strains [15]. The mode of infection is rather inefficient compared to the well known modes of vertical transmission through milk and seminal fluid. This implies that there might be two major forms of mouse mammary tumor virus. The A and B forms, as recognized recently by Callahan et al. [8], using molecular biological techniques, could easily have evolved from each other after horizontal transmission followed by long isolation and maintenance of each of the forms through vertical transmission as slowly diverging endogenous viral genes, one group of which eventually looses its identity as a true infectious virus.

\section{References}

[1] Andervont, H. B. (1945). Relation of milk influence to mammary tumors of hybrid mice. J. Natl. Cancer Inst., 5, 391-395.
[2] Andervont, H. B. (1963). In utero transmission of the mouse mammary tumor agent. J. Natl. Cancer Inst., 31, 261-272.

[3] Bentvelzen, P., and Brinkhof, J. (1977). Organ distribution of exogenous murine mammary tumor virus as determined by bioassay. Eur. J. Cancer, 13, 241-245.

[4] Bentvelzem, P., and Hilgers, J. (1980). The murine mammary tumor virus. In Viral Oncology, pp. 331355, Klein, G. (edit), Raven Press Inc., New York.

[5] Bittner, J. J. (1936). Some possible effects of nursing on the mammary tumor incidence in mice. Science, 84, 162.

[6] Blair, P. B. (1968). The mammary tumor virus (MTV). Curr. Top. Microbiol. Immunol., 45, 165. Berlin : Springer Verlag.

[7] Blair, P. B., and Lane, M. A. (1974). Immunologic evidence for horizontal transmission of MTV. J. Immunol., 113, 1446-1449.

[8] Callahan, R., Drohan, W., Callahan, D., D'Hoostelaere, L., and Potter, M. (1982). Novel class of mouse mammary tumor virus-related DNA sequences found in all species of Mus, including mice lacking the virus proviral genome. Proc. Nat. Acad. Sci., 69, 4113-4117.

[9] Dmochowski, L. (1953). The milk agent in the origin of mammary tumors in mice. Adv. Cancer Res., 1, 104-172.

[10] Foulds, L. (1949). Mammary tumors in hybrid mice : the presence and transmission of the mammary tumor agent. Br. J. Cancer, 3, 230-239.

[11] Hilgers, J., and Bentvelzen, P. (1978). Interaction between viral and genetic factors in murine mammary cancer. Adv. Cancer Res., 26, 143-195.

[12] Imai, S., and Hilgers, J. (1979). Levels of mammary tumor virus proteins (MTVp27 and MTVgp52) in the milk of low and high mammary cancer mouse strains of Japanese origin compared with European and American strains. Int. J. Cancer, 24, 359-364.

[13] Imai, S., Morimoto, J., Tsubura, Y., and Hilgers, J. (1980). Mammary tumor virus antigen expression in inbred mouse strains of European origin established in Japan. Gann, 71, 419-424.

[14] Imai, S., Tsubura, Y., and Hilgers, J. (1983). A new locus (Mtv-4) for endogenous mammary tumor virus expression and early mammary tumor development in the SHN mouse strain. J. Natl. Cancer Inst., 71, 517-521.

[15] Imai, S., Morimoto, J., Tsubura, Y., Iwai, Y., Okumoto, M., Takamori, Y., Tsubura, A., and Hilgers, J. (1983). Tissue and organ distribution of mammary tumor virus antigens in low and high mammary cancer strain mice. Eur. J. Cancer Clin. Oncology, 19, 1011-1019.

[16] Jackson, L. S. (1933). The existence of nonchromosomal influence in the incidence of mammary tumor in mice. Science, 78, 465-466.

[17] Korteweg, R. (1934). Prosfondervindelijke onderzoekinger aangande erfelijkheid van kanker. Ned. Trijdschr. Geneesk., 78, 240-245.

[18] Lopez, D. M., Ortismuniz, G., and Sigel, M. M. (1976). Macrophage migration inhibition and lymphocyte stimulation with mammary tumor virus 
associated antigens in BALB/c mice. Proc. Soc. Exp. Biol. Med., 151, 225-230.

[19] Mühlbock, O. (1952). Studies on the transmission of the mouse mammary tumor agent by the male parent. J. Natl. Cancer Inst., 12, 819-837.

[20] Nandi, S., and McGrath, C. M. (1973). Mammary neoplasia in mice. Adv. Cancer Res., 17, 353-414.

[21] Pogossiantz, H. (1956). Some data on the experimental studies on the nature of mammary cancer in mice carried out in the Soviet Union. Acta Unio Int. Contra Cancerum, 12, 690-700.

[22] Rongey, R. W., Abtin, A. H., Estes, J. D., and Gardner, M. B. (1975). Mammary tumor virus particles in the submaxillary gland, seminal vesicle, and nonmammary tumors of wild mice. J. Natl. Cancer Inst., 54, 1149-1156.

[23] Strand, M., Lilly, F., and August, J. T. (1974). Host control of endogeneous murine leukemia virus gene expression : concentrations of viral proteins in high and low leukemia mouse strains. Proc. Natl. Acid. Sci. (Wash.), 17, 3682-3686.

[24] Tsubura, Y., Imai, S., Morimoto, J., and Hilgers, J. (1981). Strain difference in the expression of mammary tumor virus antigen in the male genital organs of mice during aging. Gann, 72, 424-429.

[25] Van Nie, R., and De Moes, J. (1977). Development of a congeneic line of the GR mouse strain without early mammary tumors. Int. J. Cancer, 20, 588-594.

\title{
マウス乳癌ウイルスの水平伝達について
}

\author{
森本純司・今井俊介・螺良義彦・Jo Hilgers* \\ 奈良県立医科大学第二病理学教室 \\ *オランダ国立癌研究所腫演生物部
}

乳癌高発系 (DD/Tbr, SHN, GR) マウスと乳癌低発 系 $\mathrm{BALB} / \mathrm{c}$ マウスとを同居, 対照群として $\mathrm{BALB} / \mathrm{c}$ 同 志を同居させ, BALB/c マウスの乳汁, 唾液腺, 乳腺 及び雄の二次生殖器中に捺ける MTV 抗原 (MTVp27, MTVgp52) の発現を Immunodiffusion (I. D.) 及び Radioimmunoassay (RIA) にて検索を行なった。 MTV がほとんど検出されない BALB/c マウスに㧊い て, 乳癌高発系マウスと約 8 ケ月間同居させた場合, 雌 同志の同居では唾液腺に, 雄同志の同居では唾液腺, 精
軎, 前立腺に MTV 抗原 (3〜 50ng/蛋白) が検出され た。また, BALB/c 雌マウスと乳癌高発系雄マウスと の交配群に扮いては同性同居群に比へて MTV 抗原は やや高值 (5〜200ng/蛋白)を示した。対照群ではMTV 抗原は検出されなかった。また, 乳癌高発系 $\mathrm{DD} / \mathrm{Tbr}$, SHN マウスの精衰（精液）ならびに唾液腺の抽出物を 乳癌低発系 DDf, BALB/c マウスに接種したところ, MTV 抗原発現及び乳癌の発生が認められ, これら臟器 の内在性 MTV の感染性及び造腫湯性が確かめられた。 